\title{
Segregation for Resistance to Eastern Filbert Blight in Progeny of 'Zimmerman' Hazelnut
}

\author{
China F. Lunde', Shawn A. Mehlenbacher ${ }^{2}$, and David C. Smith ${ }^{3}$ \\ Department of Horticulture, 4017 Agricultural and Life Sciences Building, Oregon State University, \\ Corvallis, OR 97331
}

AdDITIONAL INDEX words. filbert, Corylus avellana, Anisogramma anomala, disease resistance

\begin{abstract}
Eastern filbert blight (EFB), caused by the fungus Anisogramma anomala (Peck) E. Müller, is an important disease of european hazelnut (Corylus avellana L.) in the Pacific northwestern United States. In 1989, a chance seedling free of EFB was discovered adjacent to a severely diseased orchard near Troutdale, Ore. This selection, subsequently named 'Zimmerman', was crossed with three susceptible selections. Based on morphological characters and incompatibility alleles, we speculated that 'Zimmerman' $\left(S_{1} S_{3}\right)$ was a hybrid between 'Barcelona' $\left(S_{1} S_{2}\right)$ and ' $G a s a w a y$ ' $\left(S_{3} S_{26}\right)$. The three seedling populations were inoculated with spores of the pathogen in a greenhouse test and assayed by indirect enzyme-linked immunosorbent assay (ELISA) and by observation of canker incidence. The observed segregation fit a 3 resistant : 1 susceptible ratio in all three progenies, in contrast to the $1: 1$ ratio found when the resistant pollinizer 'Gasaway' was crossed to susceptible genotypes. Random amplified polymorphic DNA (RAPD) marker UBC $152_{800}$ linked to the resistance gene in 'Gasaway' co-segregated with the resistant phenotype in all three populations with $2 \%, 4 \%$, and $6 \%$ recombination, respectively. Seed germination and transplanting records did not provide evidence of selection in favor of resistant seedlings. Pollen germination was $71 \%$ in 'Gasaway', 29\% in 'Zimmerman', and 18\% in 'Barcelona', indicating possible selection at the gametophytic level. Subsequently 16 resistant seedlings of 'Zimmerman' were crossed with the highly susceptible selection OSU 313.078. Segregation fit a 3:1 ratio in 14 of the 16 progenies, and showed a surplus of resistant seedlings in the other two. None showed a $1: 1$ segregation. Resistance co-segregated with two RAPD markers that flank the 'Gasaway' resistance allele. To test allelism of resistance from 'Gasaway' and 'Zimmerman', VR 6-28 with resistance from 'Gasaway' was crossed with 'Zimmerman'. Eight resistant selections from this progeny were crossed with OSU 313.078. Five of the eight progenies segregated $3: 1$, two progenies segregated $1: 1$, and OSU 313.078 x OSU 720.056 gave only resistant offspring. The ratios indicate that OSU 720.056 is homozygous resistant and that 'Zimmerman' and 'Gasaway' share a common resistance allele. Reciprocal translocations have been reported in hazelnut cultivars, including 'Barcelona', the leading cultivar in Oregon. 'Zimmerman' appears to be a hybrid of 'Barcelona' and 'Gasaway', but because of cytogenetic abnormalities, 'Zimmerman' may have inherited two copies of the chromosome region that contain the resistance locus and flanking RAPD markers. If the region containing the resistance were attached to two independent centromeres, a 3:1 segregation ratio for disease response and flanking markers would be expected, and we propose this as the most likely explanation. Resistance from 'Gasaway' and 'Zimmerman' has been called "immunity" or "complete resistance." However, we noted a few seedlings with small cankers, nearly all of which lacked sporulating stromata. Flanking RAPD markers indicate that the resistance allele is present in these seedlings. Although not "immune" or "completely resistant," 'Gasaway' and 'Zimmerman' transmit a very high level of resistance.
\end{abstract}

Oregon is the top producer of hazelnuts in the United States (Mehlenbacher and Olsen, 1997) and the industry is under threat by the fungus Anisogramma anomala, which causes the perennial canker disease eastern filbert blight. This disease is detrimental to production (Johnson et al., 1996) and is now present throughout the Willamette Valley. Host genetic resistance is a desirable way to avoid the expense and time commitment involved in scouting, pruning, and spraying to control this disease (Mehlenbacher, 1995).

Most resistant selections in the hazelnut breeding program at Oregon State University (OSU) derive their resistance from a single source, the obsolete pollinizer 'Gasaway'. Resistance

Received for publication 17 Apr. 2006. Accepted for publication 25 June 2006. A technical paper of the Oregon Agricultural Experiment Station. This research was supported in part by the Oregon Hazelnut Commission and a specific cooperative agreement with the United States Department of Agriculture, Agricultural Research Service (USDA, ARS). This paper is adapted from a thesis submitted by C.F. Lunde in partial fulfillment of the requirements for a M.S. degree.

1Former Graduate Research Assistant. Current address: USDA, ARS Plant Gene Expression Center, 800 Buchanan Street, Albany, CA 94710.

2Professor, to whom reprint requests should be addressed; e-mailmehlenbs@hort. oregonstate.edu.

${ }^{3}$ Senior Research Assistant. from 'Gasaway' is conferred by a dominant allele at a single locus (Coyne et al., 1998; Mehlenbacher et al., 1991). It would be beneficial to find new sources of genetic resistance. There is concern that the release of cultivars carrying the 'Gasaway' resistance will increase selection pressure on the pathogen, causing it to shift virulence (Pinkerton et al., 1998). A similar scenario occurred in apple (Malus $\times$ domestica Borkh.), in which the scab pathogen [Venturia inaequalis (Cooke) Aderh.] overcame resistance conferred by $V_{m}$ (Williams and Brown, 1968) and $V_{f}$ (Fischer et al., 1994; Parisi et al., 1993).

Davis and Mehlenbacher(1997) used bulked segregant analysis to find five RAPD markers linked to resistance in populations segregating for the 'Gasaway' allele. One of these, UBC $152_{800}$, has proven easy to score and useful for marker-assisted selection in progenies segregating for resistance (Mehlenbacher et al., 2004). Additional RAPD markers were subsequently reported (Mehlenbacher et al., 2004, 2006). Two markers that flank the resistance allele, UBC $152_{800}$ and UBC $268_{580}$, are currently used in marker-assisted selection.

In 1989, J. Pinkerton, a plant pathologist at the Horticultural Crops Research Lab of the United States Department of Agriculture, Agricultural Research Service, in Corvallis, Ore., found an 
uninfected chance seedling growing next to a severely infested orchard near Troutdale, Ore. The orchard was owned by the Zimmerman family so the seedling was named 'Zimmerman' (J. Pinkerton, personal communication). Scions of 'Zimmerman' were collected, grafted, and inoculated with the pathogen several times in a severe greenhouse test as described by Coyne et al. (1996). The plants produced neither signs of the pathogen nor symptoms of EFB. The reaction to inoculation is identical to that seen in 'Gasaway', and since they share a common incompatibility allele $\left(S_{3}\right)$, it seemed likely that 'Zimmerman' derived its resistance from 'Gasaway'. We generated several sets of progenies to clarify the inheritance of resistance from 'Zimmerman' and in this paper report the disease responses and RAPD marker data.

\section{Materials and Methods}

Plant Materials. In Feb. 1992, three seedling populations were created using three different advanced selections from the breeding program as seed parents with 'Zimmerman' as the pollen parent in controlled hybridizations, using standard techniques (Thompson et al., 1996). The three seed parents are susceptible to EFB and have diverse pedigrees (Fig. 1). Since progeny of 'Gasaway' segregate 1 resistant: 1 susceptible (Mehlenbacher et al., 1991), a similar ratio was expected in the three 'Zimmerman' populations. In 1993, resistant selection VR 6-28 ('Riccia di Talanico' x 'Gasaway') was crossed with 'Zimmerman' to investigate allelism of the two sources of resistance. In 2000, eight selections from this progeny were crossed to highly susceptible selection OSU 313.078, which is from a cross of OSU 23.017 ('Barcelona' x 'Extra Ghiaghli') x 'Tonda Gentile delle Langhe'. Additionally, 16 resistant seedlings from crosses of two susceptible selections, OSU 342.019 and OSU 350.089, with 'Zimmerman' were crossed with OSU 313.078 in 2000 to further investigate segregation ratios.

Nuts were harvested in August from pollinated branches, held in a cool room at $4{ }^{\circ} \mathrm{C}$ for 2 months, soaked in water for $4 \mathrm{~d}$, and then stratified in moist vermiculite at $4{ }^{\circ} \mathrm{C}$ for about 4 months. Nuts that failed to germinate were partially cracked by hand and treated with $50 \mathrm{mg} \cdot \mathrm{L}^{-1}$ gibberellic acid to break dormancy. After germination, they were planted in 64-cell flats $(44.13 \times 44.13 \mathrm{~cm})$ and later potted in 3.8- or 5-L pots in a mix containing equal volumes of peat, pumice, and fine douglas fir [Pseudotsugamenziesii (Mirbel) Franco] bark dust. Later, $9 \mathrm{~g}$ of Sierra 3-4 month release fertilizer (17N-2.6P-9.96K with micronutrients; The Scotts Co., Marysville, Ohio) was added to each pot. Supplemental fertilizer treatments with Peters formula (20N-8.7P-16.6K; The Scotts Co.) were made as needed. Plants were grown in a glasshouse under optimal conditions $\left(24^{\circ} \mathrm{C}\right.$ day/18 ${ }^{\circ} \mathrm{C}$ night $)$ during the summer months. Seedlings from 1992 crosses were hardened outdoors in Sept. 1993, and planted in the field in Oct. 1993 at a spacing of $0.92 \mathrm{~m}$ in rows spaced $3.05 \mathrm{~m}$ apart.

In Dec. 1995, scions were collected from seedlings planted in 1993. Scions were stored at $0{ }^{\circ} \mathrm{C}$ until grafted onto C. avellana rootstocks in Spring 1996. The grafted trees, three of each seedling, were potted as described above and kept in a glasshouse $\left(24^{\circ} \mathrm{C}\right.$ day $/ 18^{\circ} \mathrm{C}$ night) with optimal watering until ready for inoculation. Scions were collected in Dec. 1997 from trees that had been scored as resistant in the first test and grafted, inoculated, and assayed in 1998 in order to confirm their phenotype. After inoculation, the trees remained in the glasshouse $\left(24^{\circ} \mathrm{C}\right.$ day/18 ${ }^{\circ} \mathrm{C}$ night) with optimal watering for 6 months prior to beginning infection assays.
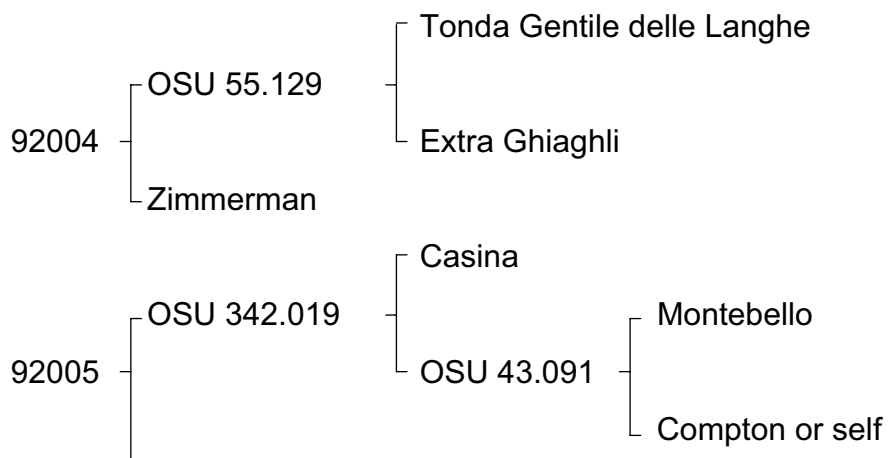

Zimmerman

$92006-\left[\begin{array}{l}\text { OSU } 350.089 \\ \text { Zimmerman }\end{array}-\left[\begin{array}{c}\text { Tombul Ghiaghli } \\ \text { Tonda Romana }\end{array}\right.\right.$

Fig. 1. Pedigrees of three hazelnut progenies.

Greenhouse inoculations. Twigs with mature stromata were collected from diseased orchards each November-December and stored at $-20{ }^{\circ} \mathrm{C}$ in polyethylene bags. Spores of the pathogen were dissected from mature perithecia and inoculum consisted of $10^{6} \mathrm{spores} / \mathrm{mL}$ suspended in distilled water. Inoculations began once four to five nodes had emerged as described by Coyne et al. (1996). Actively growing shoot tips, usually two to three per grafted tree, were marked with tape three or four nodes below the apical meristem to indicate the place of inoculation. Chamber frames were constructed of polyvinyl chloride tubing $(1.27 \mathrm{~cm}$ diameter) placed on top of a bench $(1.22 \times 3.44 \mathrm{~m})$ and covered with white 0.10 -mm-thick polyethylene sheeting. About 75 trees were placed in each of two inoculation chambers. A humidifier programmed to run from 1200 to $1800 \mathrm{HR}$ and from 0000 to 0400 HR was placed in each chamber and the plastic was fastened with clothespins. Five days later, the chambers were opened for $2 \mathrm{~d}$. Inoculations were then repeated; all trees received a total of three inoculations.

INFECTION ASSAYS FOR GREENHOUSE-INOCULATED TREES. Anisogramma anomala was detected in susceptible genotypes using three assays. ELISA was performed on inoculated shoots of each of two grafted trees from each original seedling as described in Coyne et al. (1996) with the exception that Nunc Maxisorp microtiter plates (catalog no. 439454; Nalge Nunc International, Rochester, N.Y.) were used instead of Corning plates (catalog no. 25860; Corning Glass Works, Corning, N.Y.). The third inoculated tree of each genotype was transported to the Southwest Washington Experiment Station in Vancouver, Wash., where they were planted in a nursery row in Feb. 1997. Canker incidence was evaluated in Feb. and June 1998. For trees inoculated in Winter 1998 , microscope sections were stained with $0.05 \%$ trypan blue in lactophenol and observed with a light microscope as described by Stone et al. (1992). Sections were scanned for hyphae in samples that gave conflicting results in other assays. Trees that showed any infection by fungal hyphae were scored as susceptible.

Field inoculations. Seedlings from crosses made in 2000 were grown in a glasshouse under optimal conditions $\left(24{ }^{\circ} \mathrm{C}\right.$ day $/ 18^{\circ} \mathrm{C}$ night) during the summer months as described above. The seedlings were moved outdoors to harden in Sept. 2001 and the following spring were transported to OSU's North Willamette 
Research and Extension Center near Aurora, Ore. The potted trees were placed under structures topped with diseased wood (Mehlenbacher et al., 2001; Pinkerton et al., 1993). The structure was equipped with an irrigation system and a timer. When wet, stromata in cankers in the diseased wood emit spores that rain down on the trees below. After 3 months of exposure, the potted trees were lined out in a nursery row. The presence of cankers was noted in Dec. 2004. Trees with very small cankers were carefully inspected for the presence of stromata.

DNA EXTRACTION AND RAPD SCREENING. DNA samples were collected from the original, field-planted seedlings from crosses made in 1993. A very young apical meristem and first leaf were sampled from each tree, and samples were rushed to the laboratory and quickly ground. The method of Lunde et al. (2000), modified from that of Davis et al. (1998), was used with no RNase treatment. When samples were needed from trees later in the season, catkins were used (Cheng et al., 1997). For 16 progenies from crosses made in 2000, young leaves were collected from the nursery row in Summer 2004, transported to Corvallis, and DNA was extracted as described by Lunde et al. (2000). For DNA samples collected from the 1993 seedlings, PCRs were performed in a volume of $15 \mu \mathrm{L}$ containing $10 \mathrm{~mm}$ of Tris- $\mathrm{HCl}$ (pH 9.0), $50 \mathrm{~mm} \mathrm{KCl,} \mathrm{0.15 \%} \mathrm{nonionic} \mathrm{surfactant} \mathrm{(Triton} \mathrm{X-100;}$ Sigma Chemical Co., St Louis), $1.5 \mathrm{~mm} \mathrm{MgCl}_{2}, 120 \mu \mathrm{m}$ each of dATP, dCTP, dGTP, and dTTP, $0.1 \mu \mathrm{M}$ of primer, 3-25 $\mathrm{ng}$ of DNA template, and 0.75 units of Taq polymerase (Promega, Madison, Wis.) (Davis, 1998). Reactions were run simultaneously using a Geneamp PCR System 9700 thermal cycler (Perkin-Elmer Corp., Foster City, Calif.). The parents of each progeny and a control containing no DNA were included. The thermal cycler program consisted of denaturation for $1 \mathrm{~min}$ at $94^{\circ} \mathrm{C}$, followed by 5 cycles of $1 \mathrm{~min}$ at $94^{\circ} \mathrm{C}, 1 \mathrm{~min} 30 \mathrm{~s}$ at $37^{\circ} \mathrm{C}, 30 \mathrm{~s}$ at $54{ }^{\circ} \mathrm{C}$ and $2 \mathrm{~min}$ at $72{ }^{\circ} \mathrm{C}$, and then 35 cycles of $15 \mathrm{~s}$ at $94^{\circ} \mathrm{C}, 45 \mathrm{~s}$ at $37^{\circ} \mathrm{C}, 30$ $\mathrm{s}$ at $54{ }^{\circ} \mathrm{C}$, and $1 \mathrm{~min} 30 \mathrm{~s}$ at $72{ }^{\circ} \mathrm{C}$. Primer extension occurred for $7 \mathrm{~min}$ at $72^{\circ} \mathrm{C}$, and then samples were held at $4{ }^{\circ} \mathrm{C}$ until they were retrieved. DNA from each tree was amplified using decamer primer UBC 152 (University of British Columbia, Vancouver, B.C., Canada). Amplification products were separated on $1.5 \%$ or $2 \%$ agarose gels, stained with ethidium bromide, visualized with a transilluminator, and photographed. RAPD markers are denoted by the primer name followed by subscripts denoting the size of the polymorphic band that each amplifies (UBC152 ${ }_{800}$ ).

For seedlings from 16 progenies from crosses made in 2000 , PCRs were performed in a volume of $15 \mu \mathrm{L}$ containing the same components and $0.3 \mu \mathrm{M}$ of primer, 3-25 $\mathrm{ng}$ of template DNA, 0.4 units of Biolase DNA polymerase (Biolase USA, Randolph, Mass.) and the ammonium-based buffer supplied by the manufacturer. Primers UBC 152 and 268 were used.

MARKer CLONING. DNA samples from 'Zimmerman', 'Gasaway', and OSU 350.089 were used in $15 \mu \mathrm{L}$ PCRs with primer UBC 152. PCR samples were compiled and dried down or ethanol precipitated. Ten microliters of the concentrated UBC $152_{800}$ fragment dissolved in autoclaved nano-filtered water were run on $2 \%$ low-melting point agarose (NuSieve; Cambrex Bio Science Rockland, Inc., Rockland, Maine) gels. The fragments were excised from the gels with a sterile blade and purified with the QIAquick kit(Qiagen, Inc., Valencia, Calif.) according to the manufacturer's instructions. This purified DNA fragment was poly-A tailed to facilitate ligation. Poly-A tailing was performed by combining 30 mм Tris- $\mathrm{HCl}$ (pH 7.3), 10 mм MgC1 12,10 mм DTT, 1 mм ATP, $0.2 \mathrm{~mm}$ dATP, 5 units of Taq polymerase, $6 \mu \mathrm{L}$ of purified fragment (about $70 \mathrm{ng}$ ), and $2.5 \mathrm{~mm} \mathrm{MgCl}_{2}$ in a volume of $10 \mu \mathrm{L}$ and incubating for $30 \mathrm{~min}$ at $70{ }^{\circ} \mathrm{C}$. Ligation reactions contained 30 mм Tris-HC1(pH 7.3), 10 mм MgC1 10 mм DTT, 1 mм ATP, 3 units ligase, about $40 \mathrm{ng}$ purified insert, and $50 \mathrm{ng}$ pGEM-T Easy Vector System (Promega). The reactions were stored overnight at $4{ }^{\circ} \mathrm{C}$. JM109 competent laclgZ $\Delta$ M15 Escherichia coli cells were transformed with the vector which contained an ampicillin resistance gene and the lac operon as selectable markers. Putative transformants were grown on LB + ampicillin media with X-Gal and IPTG for blue/white screening. The presence of the desired insert was confirmed with PCR and by digestion with EcoRI (0.5 $\mathrm{U}$ of enzyme per $50 \mathrm{ng}$ DNA at $37^{\circ} \mathrm{C}$ for $1 \mathrm{~h}$ ) to cut the plasmid at sites flanking the position where the insert should be. After electrophoresis, the fragment size was estimated by comparison with a 100-bp ladder (Promega). Only colonies with an insert of the correct size were multiplied by overnight incubation in LB broth. Plasmid DNA was then isolated from these cultures with the QIAprep Spin Plasmid Miniprep kit (Qiagen) as described by the supplier. The concentration of the purified plasmid DNA was measured with a Hoefer DyNAQuant 200 fluorometer (Hoefer Pharmacia Biotech Inc., San Francisco) and sequenced on an ABI 373A automated sequencer (Applied Biosystems, Perkin-Elmer, Foster City, Calif.). Sequences were edited using GDE (Smith et al., 1994). Alignment, sequence homology, and restriction enzyme sites were analyzed using GCG version 9 (University of Wisconsin Genetics Computer Group, Madison).

Pollen Germination test. Elongated catkins were collected from 'Barcelona', 'Zimmerman', and 'Gasaway' in late Jan. 1999 and laid out on paper overnight. The anthers dehisced and the pollen was poured into glass vials, plugged with cotton, and frozen until the germination test was performed. Germination medium was prepared as described by Kim et al. (1985). Pollen was sprinkled over petri dishes with quadrant dividers. Three plates were made for each genotype and plates were randomized on the bench top and left overnight (12-15 h) at about $21{ }^{\circ} \mathrm{C}$. Pollen grains were scored as having germinated if pollen tubes were longer than the diameter of the grain. One reading of approximately 100 grains was made per quadrant and recorded as percent germination.

\section{Results}

Resistant phenotypes represented about $83 \%$ of the total in the three progenies from crosses made in 1992. The observed segregation fit a ratio of 3 resistant: 1 susceptible in all three progenies (Table 1), but the pooled data showed a slight surplus of resistant seedlings. The percentages of resistant seedlings are greater than the $1: 1$ that would be expected if 'Zimmerman' were heterozygous at a single locus. A total of nine trees, including at least one in each progeny, displayed an intermediate phenotype (Table 1). On these trees, the cankers were small and nonsporulating, and hyphae could not be detected with the ELISA technique or with microscopic examination of stained tissue. The UBC $152_{800}$ marker was present in all nine plants. These seedlings were considered resistant in goodness-of-fit tests. When seedlings with intermediate phenotypes were excluded, the fit to a $3: 1$ ratio was better but the ratio was still far from $1: 1$.

Categorization by phenotype was congruent using the ELISA technique and scoring in the nursery, indicating that the lowerthan-expected frequency of infected plants was not due to a large number of disease escapes or error in technique. Furthermore, a second test was performed on all seedlings that were scored as resistant in the first test. The RAPD marker UBC $152_{800}$, which is 
Table 1. Response to greenhouse inoculation of three hazelnut progenies with Anisogramma anomala spores and goodness of fit to $3: 1$ ratio.

\begin{tabular}{llrrrrr}
\hline & & \multicolumn{3}{c}{ Disease response (no. trees) } & & \\
\cline { 3 - 5 } Progeny no. & Parents & Resistant & Small cankers & Susceptible & $\chi^{2}$ & $P$ \\
\hline 92004 & OSU 55.129 x 'Zimmerman' & 42 & 1 & 7 & 3.23 & 0.072 \\
92005 & OSU 342.019 x 'Zimmerman' & 34 & 5 & 10 & 0.55 & 0.458 \\
92006 & OSU 350.089 x 'Zimmerman' & 39 & 3 & 8 & 2.16 & 0.142 \\
Pooled data & & 115 & 9 & 25 & 5.37 & 0.020 \\
\hline
\end{tabular}

${ }^{2}$ Trees with small cankers but no sporulating stromata were considered resistant.

Table 2. Co-segregation of disease response and presence of RAPD marker UBC $152_{800}$ in three hazelnut progenies inoculated with Anisogramma anomala spores in the greenhouse.

\begin{tabular}{|c|c|c|c|c|c|c|}
\hline \multirow[b]{3}{*}{ Progeny no. } & \multirow[b]{3}{*}{ Parents } & \multicolumn{4}{|c|}{ Disease response (no. trees) } & \multirow{3}{*}{$\begin{array}{c}\text { Fraction } \\
\text { recombination }\end{array}$} \\
\hline & & \multicolumn{2}{|c|}{ Resistant } & \multicolumn{2}{|c|}{ Susceptible } & \\
\hline & & Present & Absent & Present & Absent & \\
\hline 92004 & OSU 55.129 x 'Zimmerman’ & 43 & 0 & 1 & 6 & 0.02 \\
\hline 92005 & OSU 342.019 x 'Zimmerman' & 39 & 0 & 2 & 8 & 0.04 \\
\hline 92006 & OSU 350.089 x 'Zimmerman' & 42 & 0 & 3 & 5 & 0.06 \\
\hline Pooled data & & 124 & 0 & 6 & 19 & 0.04 \\
\hline
\end{tabular}

linked to the dominant resistance allele in 'Gasaway', segregates in almost exactly the same proportion as the resistant phenotype, exhibiting only $2 \%, 4 \%$, and $6 \%$ recombination between the marker and the resistance phenotype in the three populations, respectively (Table 2). The DNA sequences of the UBC $152_{800}$ RAPD markers in 'Zimmerman' and 'Gasaway' were nearly identical (99.25\% identity, data not shown). UBC $152_{800}$ from 'Gasaway' is GenBank accession no. CC875208.

Some postzygotic mechanisms were investigated but discounted as explanations for the low incidence of infection. Nut germination and transplanting records did not provide evidence of selection in favor of resistant seedlings. Two progenies (92005 and 92006) included nondormant seedlings (Thompson et al., 1985), most of which were rogued prior to planting in the field. The remainder of the nondormant seedlings suffered cold injury in the field. The third progeny, 92004, does not segregate for nondormancy, but gave a proportion of resistant plants similar to that in the other two (Tables 1-2). Thus it does not appear that the high frequency of resistant seedlings was due to selection against nondormants. Likewise, the records of moldy or rotted kernels, stunted seedlings, seedlings with roots but no shoots, or twins failed to indicate that selection during stratification or transplanting was responsible for the high percentage of resistant seedlings. The stratification procedure is fairly long, yet the similarities in the percentage of resistant seedlings make it unlikely that one of these was the cause of the observed surplus of resistant seedlings.

Pollen germination was $29 \%$ for 'Zimmerman', $71 \%$ for 'Gasaway', and $18 \%$ for 'Barcelona', indicating that selection at the gametophytic level was possible.

Sixteen resistant seedlings of 'Zimmerman' were crossed with the highly susceptible selection OSU 313.078. Segregation fit a $3: 1$ ratio in 14 of the 16 progenies, and showed a surplus of resistant seedlings in the other two (Tables 3-4). No progeny showed a 1:1 segregation ratio. OSU 313.078 produces no nondormant offspring. Resistance co-segregated with the two RAPD markers (UBC152 $2_{800}$ and UBC268 ${ }_{580}$ ) that flank the 'Gasaway' resistance allele (Table 3). Of 18 selections from a cross of VR 6-28 x 'Zimmerman', only one was susceptible. This fits a 7:1 ratio although the sample size is small.

To test allelism of resistance from 'Gasaway' and 'Zimmerman', eight selections from a cross of VR 6-28 x 'Zimmerman' were crossed with OSU 313.078. Five of the eight progenies segregated $3: 1$, two progenies segregated $1: 1$, and OSU $313.078 \times$ OSU 720.056 gave only resistant offspring (Table 5). This indicates that OSU 720.056 is homozygous resistant and that 'Zimmerman' and 'Gasaway' share a common resistance allele.

\section{Discussion}

After observing a high frequency of resistant seedlings in three progenies, we looked at segregation distortion as an explanation. The phenomenon is common, affects diverse types of plants including annuals and perennials, and it is likely that there are many mechanisms behind it. It has been reported in perennial crops including poplar (Populus L.) (Bradshaw and Stettler, 1994), douglas fir(Jermstad et al., 1994), eucalyptus (Eucalyptus L'Hér.) (Grattapaglia and Sederoff, 1994), cherimoya (Annona cherimola Mill.) (Perfectti and Pascual, 1996), and avocado (Persea americana Mill.) (Torres et al., 1986). In hazelnut, distortion was found to be common in isozyme analyses (Cheng, 1992; Rovira et al., 1993). Clonally propagated crops seem especially prone to distortion, and within this group distortion has been attributed to genetic load (Bradshaw and Stettler, 1994) or accumulation of somatic mutations (Klekowski, 1988).

There are two possible explanations for the unexpectedly high frequency of resistant genotypes in these populations. One is that 'Zimmerman' indeed inherited resistance from 'Gasaway', but that some mechanism of segregation distortion is acting in favor of resistant genotypes in seedling populations. Selection pressure on male or female germline cells or postzygotic selection pressure before the trait of interest is evaluated will affect segregation. These can be genes important during sporogenesis, for proper functioning of germ cells, for seed development, for germination, or for plant growth (Xu et al., 1997; Zamir and Tadmor, 1986). Similarly, artificial selection for traits linked to these pre- or postzygotic factors will distort segregation.

One cause of prezygotic selection is meiotic drive. This is the preferential retention of one member of a pair of heterozygous alleles or one heteromorphic chromosome such that it is transmitted to more than half of the resulting meiocytes (Lyttle, 1991). Chromosome loss can also function during meiosis but is most common in interspecific crosses (Bradshaw and Stettler, 1994). 
Table 3. Segregation for eastern filbert blight disease scores and presence of two RAPD markers in 16 hazelnut progenies. Potted trees were exposed to eastern filbert blight under structures topped with diseased wood. Highly susceptible selection OSU 313.078 was the female parent of all progenies. All pollen parents are seedlings of 'Zimmerman'.

\begin{tabular}{|c|c|c|c|c|c|c|c|c|}
\hline & $\begin{array}{l}\text { Disease response } \\
\text { UBC } 152-800 \\
\text { UBC } 268-580\end{array}$ & $\begin{array}{c}\text { Resistant } \\
\text { Present } \\
\text { Present }\end{array}$ & $\begin{array}{c}\text { Small } \\
\text { cankers } \\
\text { Present } \\
\text { Present }\end{array}$ & $\begin{array}{c}\text { Resistant } \\
\text { Absent } \\
\text { Present }\end{array}$ & $\begin{array}{c}\text { Resistant } \\
\text { Present } \\
\text { Absent }\end{array}$ & $\begin{array}{c}\text { Susceptible } \\
\text { Absent } \\
\text { Absent }\end{array}$ & $\begin{array}{c}\text { Susceptible } \\
\text { Absent } \\
\text { Present }\end{array}$ & $\begin{array}{c}\text { Susceptible } \\
\text { Present } \\
\text { Absent }\end{array}$ \\
\hline Progeny no. & \multicolumn{8}{|c|}{ Male parents } \\
\hline \multicolumn{9}{|c|}{ Male from OSU 350.089 x 'Zimmerman' } \\
\hline 00031 & 653.016 & 62 & 5 & 1 & 0 & 10 & 2 & 0 \\
\hline 00037 & 669.066 & 57 & 3 & 2 & 0 & 16 & 2 & 0 \\
\hline 00038 & 669.070 & 57 & 0 & 0 & 1 & 20 & 2 & 0 \\
\hline 00039 & Epsilon & 17 & 1 & 1 & 0 & 4 & 0 & 0 \\
\hline \multicolumn{9}{|c|}{ Male from OSU 342.019 x 'Zimmerman' } \\
\hline 00032 & 659.010 & 32 & 4 & 1 & 1 & 18 & 3 & 0 \\
\hline 00033 & 659.022 & 49 & 3 & 4 & 0 & 9 & 3 & 0 \\
\hline 00034 & 659.033 & 48 & 4 & 0 & 0 & 19 & 1 & 1 \\
\hline 00035 & 659.044 & 67 & 1 & 1 & 0 & 7 & 1 & 0 \\
\hline 00036 & 659.046 & 53 & 1 & 0 & 0 & 23 & 1 & 1 \\
\hline 00040 & 669.094 & 58 & 3 & 0 & 1 & 17 & 1 & 0 \\
\hline 00041 & 669.095 & 49 & 7 & 2 & 0 & 20 & 2 & 0 \\
\hline 00042 & 669.104 & 52 & 2 & 2 & 0 & 21 & 1 & 1 \\
\hline 00043 & 669.113 & 52 & 5 & 0 & 2 & 19 & 0 & 0 \\
\hline 00044 & Zeta & 46 & 1 & 2 & 0 & 9 & 0 & 0 \\
\hline 00045 & 670.098 & 36 & 1 & 1 & 0 & 15 & 1 & 0 \\
\hline 00046 & 670.106 & 51 & 3 & 3 & 1 & 19 & 2 & 0 \\
\hline
\end{tabular}

Table 4. Goodness-of-fit tests to a 3:1 ratio for disease response and presence of two RAPD markers in 16 hazelnut progenies. Potted trees were exposed to eastern filbert blight under structures topped with diseased wood. All pollen parents are seedlings of 'Zimmerman'.

\begin{tabular}{|c|c|c|c|c|c|c|c|c|c|c|c|c|c|}
\hline \multirow{2}{*}{$\begin{array}{l}\text { Progeny } \\
\text { no. }\end{array}$} & \multirow[b]{2}{*}{ Parents } & \multicolumn{2}{|c|}{ Disease response ${ }^{z}$} & \multirow[b]{2}{*}{$\chi^{2}$} & \multirow[b]{2}{*}{$P$} & \multicolumn{2}{|c|}{ UBC $152-800$} & \multirow[b]{2}{*}{$\chi^{2}$} & \multirow[b]{2}{*}{$P$} & \multicolumn{2}{|c|}{ UBC 268-580 } & \multirow[b]{2}{*}{$\chi^{2}$} & \multirow[b]{2}{*}{$P$} \\
\hline & & Resistant & Susceptible & & & Present & Absent & & & Present & Absent & & \\
\hline & Male from OSU 35 & $089 \times$ x Zim & ierman' & & & & & & & & & & \\
\hline 00031 & $313.078 \times 653.016$ & 68 & 12 & 4.27 & 0.04 & 67 & 13 & 3.27 & 0.07 & 70 & 10 & 6.67 & 0.01 \\
\hline 00037 & $313.078 \times 669.066$ & 62 & 18 & 0.27 & 0.61 & 60 & 20 & 0.00 & 1.00 & 64 & 16 & 1.07 & 0.30 \\
\hline 00038 & $313.078 \times 669.070$ & 58 & 22 & 0.27 & 0.61 & 58 & 22 & 0.27 & 0.61 & 59 & 21 & 0.07 & 0.80 \\
\hline \multirow[t]{2}{*}{00039} & 313.078 x Epsilon & 19 & 4 & 0.71 & 0.40 & 18 & 5 & 0.13 & 0.72 & 19 & 4 & 0.71 & 0.40 \\
\hline & Male from OSU 34 & $019 x^{\prime} \mathrm{Zim}$ & ierman' & & & & & & & & & & \\
\hline 00032 & $313.078 \times 659.010$ & 38 & 21 & 3.53 & 0.06 & 37 & 22 & 4.75 & 0.03 & 40 & 19 & 1.63 & 0.20 \\
\hline 00033 & $313.078 \times 659.022$ & 56 & 12 & 1.96 & 0.16 & 52 & 16 & 0.08 & 0.78 & 59 & 9 & 5.02 & 0.03 \\
\hline 00034 & $313.078 \times 659.033$ & 52 & 21 & 0.55 & 0.46 & 53 & 20 & 0.22 & 0.64 & 53 & 20 & 0.22 & 0.64 \\
\hline 00035 & $313.078 \times 659.044$ & 69 & 8 & 8.77 & 0.00 & 68 & 9 & 7.28 & 0.01 & 70 & 7 & 10.39 & 0.00 \\
\hline 00036 & $313.078 \times 659.046$ & 54 & 25 & 1.86 & 0.17 & 55 & 24 & 1.22 & 0.27 & 55 & 24 & 1.22 & 0.27 \\
\hline 00040 & $313.078 \times 669.094$ & 62 & 18 & 0.27 & 0.61 & 62 & 18 & 0.27 & 0.61 & 62 & 18 & 0.27 & 0.61 \\
\hline 00041 & $313.078 \times 669.095$ & 58 & 22 & 0.27 & 0.61 & 56 & 24 & 1.07 & 0.30 & 60 & 20 & 0.00 & 1.00 \\
\hline 00042 & $313.078 \times 669.104$ & 56 & 23 & 0.71 & 0.40 & 55 & 24 & 1.22 & 0.27 & 57 & 22 & 0.34 & 0.56 \\
\hline 00043 & $313.078 \times 669.113$ & 59 & 19 & 0.02 & 0.90 & 59 & 19 & 0.02 & 0.90 & 57 & 21 & 0.15 & 0.69 \\
\hline 00044 & $313.078 \times$ Zeta & 49 & 9 & 2.78 & 0.10 & 47 & 11 & 1.13 & 0.29 & 49 & 9 & 2.78 & 0.10 \\
\hline 00045 & $313.078 \times 670.098$ & 38 & 16 & 0.62 & 0.43 & 37 & 17 & 1.21 & 0.27 & 39 & 15 & 0.22 & 0.64 \\
\hline 00046 & $313.078 \times 670.106$ & 58 & 21 & 0.11 & 0.75 & 55 & 24 & 1.22 & 0.27 & 59 & 20 & 0.00 & 0.95 \\
\hline
\end{tabular}

zTwo seedlings in progeny 00035 and one seedling in progeny 00042 showed no disease but lacked the two flanking markers. These were considered escapes and not included in this table.

Maternal abortion or competition between megaspores can cause distorted segregation. However, the first three progenies were produced by unrelated seed parents, decreasing the likelihood that this mechanism functions in the 'Zimmerman' progenies.

Another cause of prezygotic selection is certation, or abnormal pollen function. Competition due to differential pollen vigor acts from pollen germination through fertilization. In Lycopersicon hirsutum Humb. and Bonpl., genes expressed in pollen give advantage in low temperatures, exemplifying that even the haploid genome is subject to selection (Zamir et al., 1982). In european hazelnut, fertilization takes place $4-5$ months after pollination. The pollen tube grows toward the ovule and forms a callosed resting stage; fertilization eventually occurs once the ovule has formed (Thompson, 1979). It is conceivable that pollen genotypes having lesser ability to complete this process would be selected against. If 'Zimmerman' is heterozygous at a single resistance locus and the pollen carrying the susceptible allele is linked to allele(s) causing poor pollen fitness, susceptible genotypes would 
Table 5. Segregation for disease response in eight hazelnut progenies to test allelism of 'Gasaway' and 'Zimmerman' resistance. Potted trees were exposed to eastern filbert blight under structures topped with diseased wood. Highly susceptible selection OSU 313.078 was the female parent of all progenies.

\begin{tabular}{|c|c|c|c|c|c|c|c|c|c|c|}
\hline \multirow[b]{2}{*}{$\begin{array}{l}\text { Progeny } \\
\text { no. }\end{array}$} & \multirow[b]{2}{*}{$\begin{array}{c}\text { Male } \\
\text { parent }^{\mathrm{z}}\end{array}$} & \multicolumn{3}{|c|}{ Disease response (no. trees) } & \multirow[b]{2}{*}{$\begin{array}{c}\text { Resistant } \\
(\%)\end{array}$} & \multirow[b]{2}{*}{$\begin{array}{c}\chi^{2} \\
(1: 1)\end{array}$} & \multirow[b]{2}{*}{$\begin{array}{c}P \\
(1: 1)\end{array}$} & \multirow[b]{2}{*}{$\begin{array}{c}\chi^{2} \\
(3: 1)\end{array}$} & \multirow[b]{2}{*}{$\begin{array}{c}P \\
(3: 1)\end{array}$} & \multirow[b]{2}{*}{$\begin{array}{c}\text { Best } \\
\text { fit }\end{array}$} \\
\hline & & Resistant & $\begin{array}{c}\text { Small } \\
\text { cankers }^{y}\end{array}$ & Susceptible & & & & & & \\
\hline 00048 & 703.062 & 60 & 0 & 20 & 75.0 & 20.00 & 0.000 & 0.00 & 1.000 & $3: 1$ \\
\hline 00049 & 703.068 & 54 & 3 & 22 & 72.2 & 15.51 & 0.000 & 0.34 & 0.559 & $3: 1$ \\
\hline 00050 & 703.076 & 62 & 2 & 15 & 81.0 & 30.39 & 0.000 & 1.52 & 0.217 & $3: 1$ \\
\hline 00051 & 703.104 & 39 & 1 & 39 & 50.6 & 0.01 & 0.910 & 25.02 & 0.000 & $1: 1$ \\
\hline 00052 & 703.109 & 36 & 0 & 10 & 78.3 & 14.70 & 0.000 & 0.26 & 0.610 & $3: 1$ \\
\hline 00053 & 720.056 & 78 & 2 & 0 & 100.0 & 80.00 & 0.000 & 26.67 & 0.000 & $1: 0$ \\
\hline 00054 & 720.057 & 37 & 1 & 14 & 73.1 & 11.08 & 0.001 & 0.10 & 0.749 & $3: 1$ \\
\hline 00055 & 720.059 & 48 & 2 & 31 & 61.7 & 4.46 & 0.035 & 7.61 & 0.006 & $1: 1$ \\
\hline
\end{tabular}

zThe pollen parents are resistant seedlings from a cross of VR 6-28 x 'Zimmerman'. VR 6-28 is from a cross of 'Riccia di Talanico' $x$ 'Gasaway' and carries the dominant allele for eastern filbert blight resistance from 'Gasaway'.

ySeedlings with small cankers and nonsporulating stromata were classified as resistant for goodness-of-fit tests.

be compromised in the offspring resulting from its use as a pollen parent. The low rate of germination of 'Zimmerman' pollen may indicate that this is the cause of distortion in these populations. Pollination germination in 'Zimmerman' was low and similar to the $40 \%$ reported for 'Barcelona' by Salesses (1973). This mechanism has been cited as a possible cause of distortion in the inheritance of isozymes in hazelnut (Rovira et al., 1993).

Some postzygotic mechanisms were discounted. No trend could be seen in the records of moldy or rotted kernels, stunted seedlings, seedlings with roots but no shoots, or twins indicating that selection during stratification or transplanting is not likely responsible for the high percentage of resistant phenotypes in these three progenies. The stratification procedure is fairly long, yet the similarities in the percentage of resistant genotypes make it unlikely that one of these is the cause of the observed distortion. Nondormant mutants were present in two of the 1992 'Zimmerman'populations, and although progeny 92004 does not segregate for nondormancy, the proportion of resistant plants in all three populations is similar (Tables 2-3). None of the progenies produced in 2000 segregated for nondormancy, yet nearly all gave a high frequency of resistant seedlings.

The likelihood of misclassification of disease phenotypes is slight because field data and greenhouse data for the 1992 progenies were consistent (Table 3 ). Inoculations of resistant seedlings were repeated and confirmed. A similar percentage $(83 \%)$ of resistant genotypes was previously reported in other plants from population 92004 (Coyne, 1995). Furthermore, the disease and RAPD marker phenotypes were in excellent agreement. The UBC $152_{800}$ marker is well-characterized and its co-segregation with the resistance phenotype in the three progenies is not due to improper scoring. Furthermore, the same 3:1 ratio was observed in the testcross populations. The UBC $268_{580}$ marker is similarly robust and cosegregated with resistance in the 16 progenies.

Chromosome translocation has been cited as a cause of low pollen viability in certain cultivars. Salesses (1973) observed quadrivalents and trivalents in pollen mother cells of 'Barcelona', 'Tonda Gentile delle Langhe', and 'Segorbe' in meiosis I. Further study revealed that the chromosome pair involved in the reciprocal translocation in 'Barcelona' was the same in 'Segorbe', 'Negret', and 'Tonda Gentile delle Langhe', but that a different translocation was present in 'Tonda di Giffoni' (Salesses and Bonnet, 1988). Because of cytogenetic abnormalities, 'Zimmerman' may have inherited two copies of the chromosome region that contains the resistance locus and flanking RAPD markers from 'Gasaway'.
If resistance were linked to two independent centromeres, a $3: 1$ segregation ratio for disease response and flanking markers would be expected. Recently, Gökirmak (2005) investigated 270 hazelnut accessions using 21 simple sequence repeat markers. At all 21 marker loci, 'Zimmerman' had one allele in common with 'Barcelona' and one allele in common with 'Gasaway'. This is strong evidence that 'Barcelona' and 'Gasaway' are the parents of 'Zimmerman'.

Our hypothesis is that 'Zimmerman' is heterozygous $\left(R_{1} r_{1} R_{2} r_{2}\right)$ at two independent loci and that only plants homozygous recessive at both loci are susceptible. This would explain the observed 3 resistant: 1 susceptible ratio in the 1993 progenies. Following this reasoning, crosses of resistant 'Zimmerman' progeny from the 1993 crosses with susceptible plants should segregate 3 resistant: 1 susceptible or 1 resistant: 1 susceptible. However, all 16 crosses of 'Zimmerman' seedlings to OSU 313.078 showed an excess of resistant seedlings, and 14 fit a $3: 1$ ratio (or higher). None exhibited a $1: 1$ ratio. In all 16 progenies, segregation for two flanking RAPD markers was highly correlated with disease response (Table 3 ).

Following the two-locus model, seedlings from a cross between VR 6-28 which carries the 'Gasaway' resistance allele and 'Zimmerman' should segregate 7 resistant: 1 susceptible. The observed 17 resistant: 1 susceptible ratio fits the expected ratio. When selections from this progeny were crossed with OSU 313.078, three segregation ratios were seen in the offspring: $3: 1$, $1: 1$ and $1: 0$. If the UBC $152_{800}$ marker were linked only to the resistance allele from 'Gasaway', the marker should segregate 1 present: 1 absent, but 3:1 ratios were observed. In order to explain these results, we hypothesize that the second locus arose from duplication of the first and that the flanking regions that produce the $\mathrm{UBC} 152_{800}$ and $\mathrm{UBC} 268_{580}$ markers were also duplicated. It is interesting to note that in the 1992 crosses, the only recombinants seen were susceptible plants with the marker. In the 2002 crosses, however, four types of recombinants were found (Table 3).

Resistance from 'Gasaway' and 'Zimmerman' has been called "immunity" or "complete resistance." However, we noted a few seedlings with small cankers but nearly all lack sporulating stromata. A few seedlings produce occasional stromata. Flanking RAPD markers were present, indicating that the resistance allele is also present in these seedlings. So although not "immune" or "completely resistant," 'Gasaway' and 'Zimmerman' transmit a very high level of resistance. 
In summation, it is hoped that increasing knowledge about novel sources of resistance to EFB will aid in the development of highly resistant cultivars. Investigation of EFB resistance in progenies of 'Zimmerman' has provided us with very useful information. Because it appears that 'Zimmerman' carries the same resistance allele as 'Gasaway', albeit two independent copies, it does not provide us with a new resistance gene, but we now know that we can use our RAPD markers in progenies segregating for resistance from 'Zimmerman'. In addition, the proportion of resistant progeny in crosses of 'Zimmerman' is much higher than when 'Gasaway' is used as the resistance source. Although 'Zimmerman' has many undesirable traits, it is a significant improvement over 'Gasaway' with respect to nut yield, nut size, and nut shape and is thus useful as a parent in breeding for disease resistance.

\section{Literature Cited}

Bradshaw, H.D., Jr. and R.F. Stettler. 1994. Molecular genetics of growth and development in Populus. II. Segregation distortion due to genetic load. Theor. Appl. Genet. 89:551-558.

Cheng, S. 1992. Isozyme variation and inheritance in hazelnut. $\mathrm{PhD}$ Diss., Oregon State University, Corvallis.

Cheng, F.S., S.K. Brown, and N.F. Weeden. 1997.ADNA extraction protocol from various tissues in woody species. HortScience 32:921-922.

Coyne, C.J. 1995. Genetic resistance to eastern filbert blight. PhD Diss., Oregon State University, Corvallis.

Coyne, C.J., S.A. Mehlenbacher, R.O. Hampton, J.N. Pinkerton, and K.B. Johnson. 1996. Use of ELISA to rapidly screen hazelnut for resistance to eastern filbert blight. Plant Dis. 80:1327-1330.

Coyne, C.J., S.A. Mehlenbacher, and D.C. Smith. 1998. Sources of resistance to eastern filbert blight in hazelnut. J. Amer. Soc. Hort. Sci. 123:253-257.

Davis, J.W. and S.A. Mehlenbacher. 1997. Identification of RAPD markers linked to eastern filbert blight resistance in hazelnut. Acta Hort. 445:553-555.

Davis, J.W. 1998. Identification and development of PCR-based markers linked to eastern filbert blight resistance in hazelnut. MS Thesis, Oregon State University, Corvallis.

Davis, J., D. Henderson, M. Kobayashi, and M.T. Clegg. 1998. Genealogical relationships among cultivated avocado as revealed through RFLP analyses. J. Hered. 89:319-323.

Fischer, C., A. Bondarenko, and E. Artamonova. 1994. Results on the stability of scab resistance in apple breeding. p. 81-85. In: H. Schmidt and M. Kellerhals (eds.). Progress in temperate fruit breeding. Kluwer Academic Publ., Dordrecht, The Netherlands.

Gökirmak, T. 2005. Characterization of european hazelnut (Corylus avellana L.) cultivars using SSR markers. MS Thesis, Oregon State University, Corvallis.

Grattapaglia, D. and R. Sederoff. 1994. Genetic linkage maps of Eucalyptus grandis and Eucalyptus urophylla using a pseudo-testcross: mapping strategy and RAPD markers. Genetics 137:1121-1137.

Jermstad, K.D.,A.M. Reem, J.R. Henifin, N.C. Wheeler, and D.B. Neale. 1994. Inheritance of restriction fragment length polymorphisms and random amplified polymorphic DNAs in coastal douglas-fir. Theor. Appl. Genet. 89:758-766.

Johnson, K.B., S.A. Mehlenbacher, J.K. Stone, J.W. Pscheidt, and J.N. Pinkerton. 1996. Eastern filbert blight of european hazelnut: It's becoming a manageable disease. Plant Dis. 80:1308-1316.

Kim, S.K., H.B. Lagerstedt, and L.S. Daley. 1985. Germination responses of filbert to $\mathrm{pH}$, temperature, glucose, fructose, and sucrose. HortScience 20:944-946.

Klekowski, E.J, Jr. 1988. Mutation, developmental selection, and plant evolution. Columbia University Press, New York.

Lunde, C.F., S.A. Mehlenbacher, and D.C. Smith. 2000. Survey of hazelnut cultivars for response to eastern filbert blight inoculation. HortScience 35:729-731.
Lyttle, T.W. 1991. Segregation distorters. Proc. Natl. Acad. Sci. USA 25:511-557.

Mehlenbacher, S.A. 1995. Progress in breeding new hazelnut cultivars in Oregon. Nucis Nwsl. 3:8-9.

Mehlenbacher, S.A., R.N. Brown, J.W. Davis., H. Chen, N.V. Bassil, D.C. Smith, and T.L. Kubisiak. 2004. RAPD markers linked to eastern filbert blight resistance in Corylus avellana. Theor. Appl. Genet. 108:651-656.

Mehlenbacher, S.A., R.N. Brown, E.R. Nouhra, T. Gokirmak, N.V. Bassil, and T.L. Kubisiak. 2006. A genetic linkage map for hazelnut (Corylus avellana L.) based on RAPD and SSR markers. Genome 49:122-133.

Mehlenbacher, S.A., M.M. Thompson, and H.R. Cameron. 1991. Occurrence and inheritance of resistance to eastern filbert blight in 'Gasaway' hazelnut. HortScience 26:410-411.

Mehlenbacher, S.A. and J. Olsen. 1997. The hazelnut industry in Oregon. Acta Hort. 445:337-345.

Mehlenbacher, S.A., A.N. Azarenko, D.C. Smith, and R. McCluskey. 2001. 'Clark' hazelnut. HortScience 36:995-996.

Parisi, L., Y. Lespinasse, J. Guillaumes, and J. Kruger. 1993. A new race of Venturia inaequalis virulent to apples with resistance due to the $V f$ gene. Phytopathology 83:533-537.

Perfectti, F. and L. Pascual. 1996. Segregation distortion of isozyme loci in cherimoya (Annona cherimoya Mill). Theor. Appl. Genet. 93:440-446.

Pinkerton, J.N., K.B. Johnson, S.A. Mehlenbacher, and J.W. Pscheidt. 1993. Susceptibility of European hazelnut clones to eastern filbert blight. Plant Dis. 77:261-266.

Pinkerton, J.N., K.B. Johnson, J.K. Stone, and K.L. Ivors. 1998. Maturation and seasonal discharge pattern of ascospores of Anisogramma anomala. Phytopathology 88:1165-1173.

Rovira, M., N. Aleta, E. Germain, and P. Arus. 1993. Inheritance and linkage relationships of ten isozyme genes in hazelnut. Theor. Appl. Genet. 86:322-328.

Salesses, G. 1973. Étude cytologique du genre Corylus. Mise en évidence d'une translocation hétérozygote chez quelques variétés de noisetier cultivé $(C$. avellana) a fertilité pollinique réduite. Annales de l'Amélioration des Plantes 23:59-66.

Salesses, G. and A. Bonnet. 1988. Étude cytogénétique d'hybrides entre variétés de noisetier (Corylus avellana) porteuses d'une translocation à l'état hétérozygote. Cytologia 53:407-413.

Smith, S.W., R. Overbeek, C.R. Woose, W. Gilbert, and P.M. Gillevet. 1994. The genetic data environment and expandable GUI for multiple sequence analysis. CABIOS 10:671-675.

Stone, J.K., K.B. Johnson, J.N. Pinkerton, and J.W. Pscheidt. 1992. Natural infection period and susceptibility of vegetative seedlings of european hazelnut to Anisogramma anomala. Plant Dis. 76:348-352.

Thompson, M.M. 1979. Growth and development of the pistillate flower and nut in 'Barcelona' filbert. J. Amer. Soc. Hort. Sci. 104:427-432.

Thompson, M.M., H.B. Lagerstedt, and S.A. Mehlenbacher. 1996. Hazelnuts. p. 125-184. In: J. Janick and J.N. Moore (eds.). Fruit breeding. Vol. 3. Nuts. Wiley, New York.

Thompson, M.M., D.C. Smith, and J.E. Burgess. 1985. Nondormant mutants in a temperate tree species, Corylus avellana L. Theor. Appl. Genet. 70:687-692.

Torres, A.M., T. Mau-Lastovicka, V. Vithanage, and M. Sedgley. 1986. Segregation distortion and linkage analysis of hand pollinated avocados. J. Hered. 77:445-450.

Williams, E.B. and A.G. Brown. 1968. Anew physiologic race of Venturia inaequalis, incitant of apple scab. Plant Dis. Rpt. 52:799-800.

Xu, Y.,L.Zhu, J. Xiao, N. Huang, and S.R. McCouch. 1997. Chromosomal regions associated with segregation distortion of molecular markers in $\mathrm{F}_{2}$, backcross, doubled haploid, and recombinant inbred populations in rice (Oryza sativa L.). Mol. Gen. Genet. 253:535-545.

Zamir, D. and Y. Tadmor. 1986. Unequal segregation of nuclear genes in plants. Bot. Gaz. 147:355-358.

Zamir, D., S.D. Tanksley, and R.A. Jones. 1982. Haploid selection for low temperature tolerance of tomato pollen. Genetics 101:129-137. 